
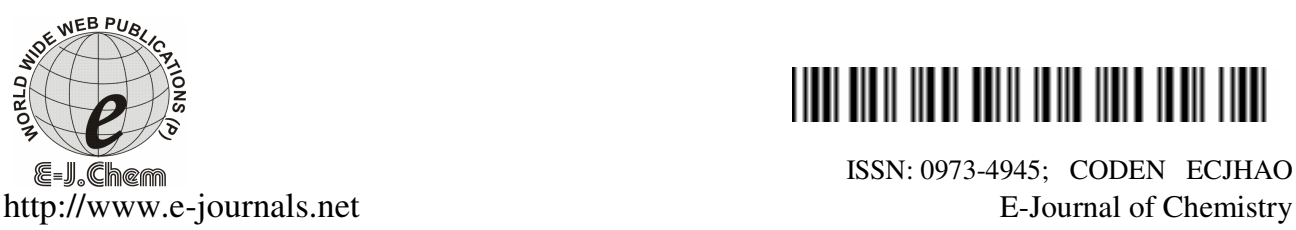

Vol. 4, No.1, pp 32-38, January 2007

\title{
Synthesis, Characterization and Antimicrobial Activity of Methylquinolino[3,2-b][1,5]benzodiazepine and Methylquinolino[3,2-b][1,5]benzoxazepine and its Various Metal Complexes
}

\author{
B. BASAVARAJU*, H.S. BHOJYA NAIK ${ }^{\#}$ and M.C. PRABHAKARA ${ }^{\#}$ \\ *Department of Biotechnology, \\ GM Institute of Technology, Davangere-577 006, \\ Karnataka, India. Phone: (08192) 233377, Fax: (08192) 233344 \\ e-mail: basavaraju_b@yahoo.co.in \\ \#Department of PG studies and Research in Industrial Chemistry, \\ School of Chemical Sciences, Kuvempu University, Shankaraghatta-577 451, Shimoga, \\ Karnataka, India. Phone: (08282) 256303, e-mail: hsb_naik@rediffmail.com
}

Received 3 July 2006; Accepted 8 September 2006

\begin{abstract}
Chloro-6-methylquinoline-3-carbaldehyde was condensed with $o$-Phenylenediammine and 2-aminophenol in presence of potassium iodide. The resulting Methylquinolino[3,2-b][1,5]benzodiazepine (MQBD) and Methylquinolino[3,2-b][1,5]benzoxazepine(MQBO) were characterized by elemental analysis and spectral studies. The metal chelates viz $\mathrm{Pd}(\mathrm{II})$, $\mathrm{Rh}$ (III) and $\mathrm{Ru}(\mathrm{III})$ of ligands were prepared and characterized by metalligand (M:L) ratio, UV-Visible, IR, ${ }^{1} \mathrm{H}$ NMR spectroscopes and magnetic properties. The antibacterial and antifungal activity of MQBD, MQBO and its metal complexes were screened against various bacteria and fungi. The results show that all these samples are good antimicrobial agents.
\end{abstract}

Keywords: 2-Chloro-6-methylquinoline-3-carbaldehyde, Antimicrobial activity, Methylquinolino[3,2-b][1,5]benzodiazepine, Methylquinolino[3,2b][1,5]benzoxazepine, quinoline.

\section{Introduction}

The quinoline skeleton is often used for the design of many synthetic compounds with diverse pharmacological properties. The 8-(diethylaminohexylamino)-6-methoxy-4-methylquinoline is highly effective against the protozoan parasite Trypanosoma cruzy, which is the agent of Chagas' disease ${ }^{1}$. The centipede, Scolopendra Subspines mutilalns L. which is 
found to contain 3,8-dihydroxyquinoline called Jineol has been prescribed for tetanus, childhood convulsions and acute heart attack $^{2}$. Cryptolepine (5-methyl-5H-indolo[3,2b]quinoline) displays a plenty of pharmacological effects, such as antimuscarinic, noradrenergic receptor antagonistic, antihypertensive, vasodilative, antithrombotic, antipyretic and anti-inflammatory properties ${ }^{3-5}$. Quinoline containing drugs particularly 4aminoquinolines, have a long and successful history as antimalarials ${ }^{6,7}$.

\section{Experimental}

\section{Materials}

All the chemicals used in the present study are of AR grade. 2-Chloro-6-methylquinoline-3carbaldehyde (Sigma-Aldrich Chemie, Germany), 2-aminophenol (S.D.Fine Chem Ltd, India) and $o$-Phenylenediammine (S.D.Fine Chem Ltd, India) were used.

\section{Measurements}

The IR spectra of ligand and its metal complexes were recorded on a SHIMADZU FTIR$8400 \mathrm{~S}$ spectrometer with $\mathrm{KBr}$ pellets in the region 250-4000 $\mathrm{cm}^{-1}$. JEOL $60 \mathrm{MH}_{\mathrm{Z}}$ spectrometer was used for recording the proton NMR spectra employing TMS as internal reference and DMSO- $\mathrm{d}_{6}$ as solvent. UV-visible spectra were measured on a SHIMADZU double beam spectrophotometer using $\mathrm{N}, \mathrm{N}^{\prime}$-dimethylformamide as a solvent at $10^{-3} \mathrm{M}$ concentration.

\section{Antibacterial activity}

Antibacterial activity of ligands and its complexes were studied against Gram positive bacteria $S$. aureus and Gram negative bacteria $P$. aerugenosa by employing paper disc method $^{8}$. The streptomycin $(100 \mathrm{mg})$ was used as a standard. For each concentration, the mean diameter of inhibition zone developed $(\mathrm{mm})$ was calculated.

\section{Antifungal activity}

The antifungal studies of ligands and its complexes were tested on the fungal strains namely, C. albicans, A. flavus and A. niger in the growth media by using Batemann poisoned food technique ${ }^{9}$. The average percentage inhibition was calculated by using the reported method $^{10}$.

\section{Synthesis of Methylquinolino[3,2-b][1,5]benzodiazepine (MQBD)}

The mixture of 2-Chloro-6-methylquinoline-3-carbaldehyde (1.569 g, $5 \mathrm{mmo}$ ) dissolved in small amount of acetic acid and $o$-Phenylenediammine $(0.541 \mathrm{~g}, 5 \mathrm{mmol})$ was taken in a 100 $\mathrm{ml}$ borosil beaker and a pinch of potassium iodide was then added. The whole mixture was made into slurry and was irradiated by placing the beaker in a microwave oven for about 10 minutes. The product obtained was poured into ice-cold water, the solid separated was filtered, dried and recrystallized (Scheme 1).

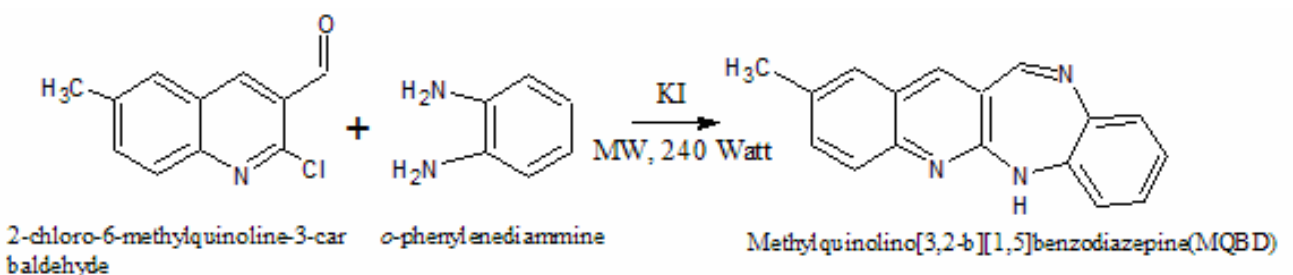

Scheme-1. Preparation of Methylquinolino[3,2-b][1,5]benzodiazepine(MQBD) 


\section{Synthesis of Methylquinolino[3,2-b][1,5]benzoxazepine(MQBO)}

The mixture of 2-aminophenol (0.11 g, 1 mmol), KOH (0.057 g, $1 \mathrm{mmol})$ and $2 \mathrm{ml}$ of DMSO were taken in a $100 \mathrm{ml}$ borosil beaker. 2-Chloro-6-methylquinoline-3-carbaldehyde (1 mmol, $0.314 \mathrm{~g}$ ) and a pinch of KI were then added. The mixture was irradiated for about two minutes in a microwave oven. The product was then hydrolyzed by pouring into icecold water. The final product separated as a solid on acidification with dilute $\mathrm{HCl}$ was then filtered, dried and purified (Scheme 2).

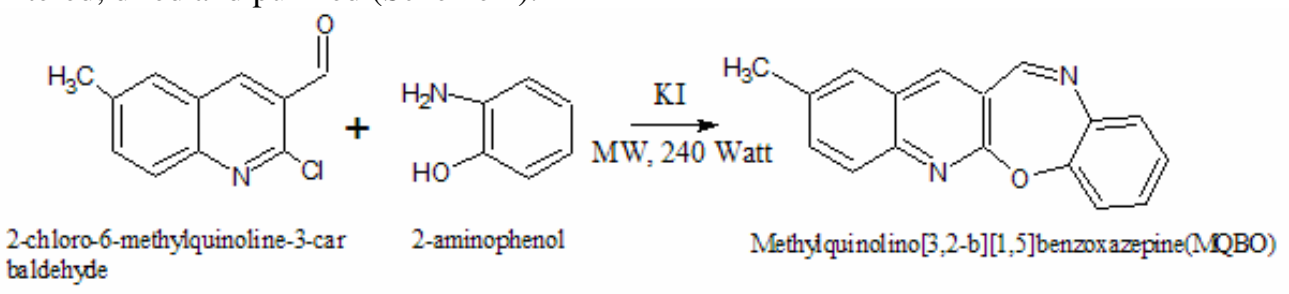

Scheme 2. Preparation of Methylquinolino[3,2-b][1,5]benzoxazepine(MQBO)

\section{General procedure for the preparation of $\mathrm{Pd}(\mathrm{II})$ complexes}

The complexes were prepared by mixing an ethanolic solution of the metal dichloride with the corresponding ligand in hot ethanol in a 1:1 molar ratio. The resultant solution was refluxed at $110{ }^{\circ} \mathrm{C}$ for three hours. When the corresponding metal complex precipitated, it was filtered, washed several times with ethanol and dried under reduced pressure.

\section{General procedure for the preparation of Rh(III) complexes}

The complexes were prepared by refluxing the rhodium(III)chloride trihydrate $(5 \mathrm{mmol})$ and the corresponding ligand $(10 \mathrm{mmol})$ in ethanol $(75 \mathrm{ml})$ for $2-3$ hours. When the metal complex precipitated, it was filtered, washed several times with hot water, warm ethanol and dried at $110-130{ }^{\circ} \mathrm{C}$.

General procedure for the preparation of $\mathrm{Ru}(\mathrm{III})$ complexes

A mixture containing $\mathrm{RuCl}_{3} .3 \mathrm{H}_{2} \mathrm{O}(2.5 \mathrm{mmol})$ and corresponding ligand $(5 \mathrm{mmol})$ was refluxed in methanol for 5 hours. The solution was cooled to room temperature. After evaporation of the solvent, the solid was collected, washed with methanol and dried under suction.

\section{Results and Discussion}

\section{Stoichiometry}

The complexes are microcrystalline coloured powder, whose melting points are higher than the pure ligand. They are stable at room temperature and are insoluble in common organic solvents. The elemental analysis data show that they are of the types $\left[\mathrm{ML}_{2} \mathrm{Cl}_{2}\right]$ where $\mathrm{M}=\mathrm{Rh}(\mathrm{III})$ ) or $\mathrm{Ru}(\mathrm{III})$ and $\left[\mathrm{PdLCl}_{2}\right]$ where $\mathrm{L}=\mathrm{MQBD}$ or MQBO. Palladium(II) and Ruthenium(III) complexes are brown to brownish red and rhodium(III) complexes are reddish.

\section{Molar conductivity}

The molar conductance values of all the complexes were determined in $10^{-3} \mathrm{M}$ DMF and are tabulated in Table 1. The conductivity values of $\mathrm{Pd}(\mathrm{II})$ complexes are in the range 28.5-29.2 mhos $\mathrm{cm}^{2} \mathrm{~mol}^{-1}$ indicating the non-electrolytic nature of the complexes ${ }^{11}$. The molar conductance values of rhodium(III) and ruthenium(III) complexes were found to be quite 
low (17.5-25.4 mhos $\left.\mathrm{cm}^{2} \mathrm{~mol}^{-1}\right)$, showing that these complexes have covalent behaviour. The observed very small conductance values show that practically no interaction occurs between the solvent and the dissolved complex. Thus the chloride ions in all these complexes are coordinated to metal ion and are not present outside the coordination sphere $^{12}$. This is consistent with the stoichiometry assumed for the complexes on the basis of analytical data.

\section{Magnetic moments}

The room temperature magnetic values (Table 1) shows that the $\operatorname{Pd}(\mathrm{II})$ complexes are diamagnetic showing square planar geometry. The octahedral $\mathrm{Rh}(\mathrm{III})$ complexes are paramagnetic and magnetic moment values are found to be in the range 1.84-1.86 $\mathrm{BM}^{13}$. The magnetic susceptibility data indicates that the $\mathrm{Ru}(\mathrm{III})$ complexes are paramagnetic with one unpaired electron. The values are in the range 1.78-1.85 $\mathrm{BM}$ that is lower than the predicted value of $2.1 \mathrm{BM}$. This low value may be due to low symmetry ligand fields or electron delocalization. This observed value is very close to the spin only value for one unpaired electron ${ }^{14}$. This suggests the low spin $d^{5}$ configuration for ruthenium(III) ion in an octahedral environment

Table 1. Physical constants of ligands and its complexes

\begin{tabular}{|c|c|c|c|c|c|c|c|c|c|}
\hline \multirow[t]{2}{*}{ Compound } & \multirow{2}{*}{$\begin{array}{l}0 \\
0 \\
0 \\
0\end{array}$} & \multicolumn{5}{|c|}{$\begin{array}{c}\text { Found (Calcd) } \\
\%\end{array}$} & \multirow{2}{*}{ 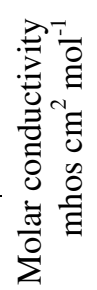 } & \multirow{2}{*}{ 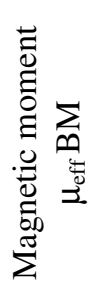 } & \multirow[t]{2}{*}{$\begin{array}{l}\text { Mol.wt. } \\
\text { found } \\
\text { (Calcd) }\end{array}$} \\
\hline & & $\mathrm{C}$ & $\mathrm{H}$ & $\mathrm{N}$ & M & $\mathrm{Cl}$ & & & \\
\hline MQBD & 74 & $\begin{array}{c}78.89 \\
(78.74)\end{array}$ & $\begin{array}{c}5.25 \\
(5.05)\end{array}$ & $\begin{array}{c}16.35 \\
(16.20)\end{array}$ & -- & -- & -- & -- & $\begin{array}{c}256.21 \\
(259.30)\end{array}$ \\
\hline MQBO & 76 & $\begin{array}{c}78.65 \\
(78.44)\end{array}$ & $\begin{array}{c}4.83 \\
(4.65)\end{array}$ & $\begin{array}{c}11.01 \\
(10.76)\end{array}$ & -- & -- & -- & -- & $\begin{array}{c}257.26 \\
(260.29)\end{array}$ \\
\hline $\left.\mathrm{Pd}(\mathrm{MQBD}) \mathrm{Cl}_{2}\right]$ & 81 & $\begin{array}{c}46.76 \\
(45.78)\end{array}$ & $\begin{array}{c}3.00 \\
(3.12)\end{array}$ & $\begin{array}{c}9.62 \\
(9.59)\end{array}$ & $\begin{array}{c}24.37 \\
(24.52)\end{array}$ & $\begin{array}{c}16.24 \\
(16.12)\end{array}$ & 28.5 & -- & $\begin{array}{c}432.59 \\
(436.63)\end{array}$ \\
\hline $\left.\mathrm{Pd}(\mathrm{MQBO}) \mathrm{Cl}_{2}\right]$ & 77 & $\begin{array}{c}46.66 \\
(45.75)\end{array}$ & $\begin{array}{c}2.76 \\
(2.81)\end{array}$ & $\begin{array}{c}6.40 \\
(6.38)\end{array}$ & $\begin{array}{c}24.32 \\
(25.12)\end{array}$ & $\begin{array}{c}16.20 \\
(16.32)\end{array}$ & 29.2 & -- & $\begin{array}{c}435.68 \\
(437.62)\end{array}$ \\
\hline $\left.\mathrm{Rh}(\mathrm{MQBD})_{2} \mathrm{Cl}_{2}\right]$ & 82 & $\begin{array}{c}58.98 \\
(57.88)\end{array}$ & $\begin{array}{c}3.78 \\
(3.68)\end{array}$ & $\begin{array}{c}12.14 \\
(12.32)\end{array}$ & $\begin{array}{c}14.86 \\
(13.68)\end{array}$ & $\begin{array}{c}10.24 \\
(10.32)\end{array}$ & 17.5 & 1.86 & $\begin{array}{c}689.36 \\
(692.42)\end{array}$ \\
\hline $\left.\mathrm{Rh}(\mathrm{MQBO})_{2} \mathrm{Cl}_{2}\right]$ & 82 & $\begin{array}{c}58.81 \\
(57.98)\end{array}$ & $\begin{array}{c}3.48 \\
(3.38)\end{array}$ & $\begin{array}{c}8.07 \\
(8.12)\end{array}$ & $\begin{array}{c}14.82 \\
(14.25)\end{array}$ & $\begin{array}{c}10.21 \\
(10.31)\end{array}$ & 19.2 & 1.84 & $\begin{array}{c}690.98 \\
(694.39)\end{array}$ \\
\hline $\left.\mathrm{Ru}(\mathrm{MQBD})_{2} \mathrm{Cl}_{2}\right]$ & 79 & $\begin{array}{c}59.13 \\
(58.25)\end{array}$ & $\begin{array}{c}3.79 \\
(3.85)\end{array}$ & $\begin{array}{c}12.17 \\
(12.24)\end{array}$ & $\begin{array}{c}14.64 \\
(14.58)\end{array}$ & $\begin{array}{c}10.27 \\
(10.38)\end{array}$ & 21.5 & 1.85 & $\begin{array}{c}688.84 \\
(690.59)\end{array}$ \\
\hline $\left.\mathrm{Ru}(\mathrm{MQBO})_{2} \mathrm{Cl}_{2}\right]$ & 72 & $\begin{array}{c}58.96 \\
(58.85)\end{array}$ & $\begin{array}{c}3.49 \\
(3.59)\end{array}$ & $\begin{array}{c}8.09 \\
(8.12)\end{array}$ & $\begin{array}{c}14.59 \\
(14.25)\end{array}$ & $\begin{array}{c}10.24 \\
(10.38)\end{array}$ & 25.4 & 1.78 & $\begin{array}{c}690.14 \\
(692.55)\end{array}$ \\
\hline
\end{tabular}




\section{Spectral study}

The electronic spectrum of Pd(II) complexes gave three bands at 16600, 21300 and $30300 \mathrm{~cm}^{-1}$ due to ${ }^{1} \mathrm{~A}_{1 \mathrm{~g}} \rightarrow{ }^{1} \mathrm{~A}_{2 \mathrm{~g}}\left(v_{1}\right),{ }^{1} \mathrm{~A}_{1 \mathrm{~g}} \rightarrow{ }^{1} \mathrm{~B}_{1 \mathrm{~g}}\left(v_{2}\right)$ and ${ }^{1} \mathrm{~A}_{1 \mathrm{~g}} \rightarrow{ }^{1} \mathrm{E}_{1 \mathrm{~g}}\left(v_{3}\right)$ transitions, respectively in a square planar configuration ${ }^{13}$. In Rh(III) complexes, the observed electronic bands around 16600, 19400 and $22300 \mathrm{~cm}^{-1}$ are due to the transitions ${ }^{1} \mathrm{~A}_{1 \mathrm{~g}} \rightarrow{ }^{3} \mathrm{~T}_{1 \mathrm{~g}},{ }^{1} \mathrm{~A}_{1 \mathrm{~g}} \rightarrow{ }^{1} \mathrm{~T}_{1 \mathrm{~g}}$ and ${ }^{1} \mathrm{~A}_{1 \mathrm{~g}} \rightarrow{ }^{1} \mathrm{~T}_{2 \mathrm{~g}}$, respectively in an octahedral structure around $\mathrm{Rh}(\mathrm{III})^{13}$. The UV-Visible spectra $\mathrm{Ru}(\mathrm{III})$ complexes showed that the complexes exhibit octahedral absorption bands in the region $24800-24570 \mathrm{~cm}^{-1}$. Only charge transfer bands, which masked the weak (spin forbidden as well as spin allowed) bands due to d-d transitions in the visible region. The bands in the range $24800-24570 \mathrm{~cm}^{-1}$ may be attributed to ${ }^{1} \mathrm{~A}_{1 \mathrm{~g}} \rightarrow{ }^{1} \mathrm{~T}_{1 \mathrm{~g}}$ charge transfer transitions ${ }^{15}$. All the Ru(III) complexes show absorption band ca. $37000 \mathrm{~cm}^{-1}$ corresponding to charge transfer transitions.

\section{IR Spectra}

The ligand MQBD shows bands at $1662 \mathrm{~cm}^{-1}$ and $3332 \mathrm{~cm}^{-1}$ due to $v(\mathrm{C}=\mathrm{N})$ and $v(\mathrm{NH})$ vibrations respectively ${ }^{16}$. These bands are shifting in the complexes indicates the coordination of nitrogen atom of quinoline and azepine moiety with the metal ions. The IR spectra of MQBO showed absorption bands at $1025 \mathrm{~cm}^{-1}$ and $1653 \mathrm{~cm}^{-1}$ for $v(C O C)$, $v(\mathrm{C}=\mathrm{N})$ respectively ${ }^{17}$. The negative shift of these bands in the complexes indicates the sites of coordination are nitrogen and oxygen atoms quinoline and azepine rings, respectively. The important IR spectral data are shown in Table 2.

Table 2. The IR and ${ }^{1} \mathrm{H}$ NMR spectral data of ligands and complexes.

\begin{tabular}{|c|c|c|c|c|c|c|}
\hline \multirow[b]{2}{*}{ Compound } & \multicolumn{5}{|c|}{ Infrared spectral data } & \multirow{2}{*}{$\begin{array}{c}{ }^{1} \mathrm{H} \text { NMR } \\
\text { spectral data } \\
\delta, \text { ppm }\end{array}$} \\
\hline & $v(\mathrm{C}=\mathrm{N})$ & $v(\mathrm{NH})$ & $v(\mathrm{COC})$ & $v \mathrm{M}-\mathrm{N}$ & $v \mathrm{M}-\mathrm{X}$ & \\
\hline MQBD & 1662 & 3332 & -- & -- & -- & $\begin{array}{c}10.80(\mathrm{~s}, 1 \mathrm{H}, \mathrm{NH}) \\
8.6(\mathrm{~s}, 1 \mathrm{H}, \mathrm{H}-\mathrm{C}=\mathrm{N}), \\
7.1-8.2(\mathrm{~m}, 11 \mathrm{H}, \mathrm{Ar}-\mathrm{H}), \\
2.7\left(\mathrm{~s}, 3 \mathrm{H}, \mathrm{CH}_{3}\right)\end{array}$ \\
\hline MQBO & 1653 & -- & 1025 & -- & -- & $\begin{array}{c}8.4(\mathrm{~s}, 1 \mathrm{H}, \mathrm{H}-\mathrm{C}=\mathrm{N}) \\
7.3-8.0(\mathrm{~m}, 11 \mathrm{H}, \mathrm{Ar}-\mathrm{H}) \\
2.6\left(\mathrm{~s}, 3 \mathrm{H}, \mathrm{CH}_{3}\right)\end{array}$ \\
\hline$\left[\mathrm{Pd}(\mathrm{MQBD}) \mathrm{Cl}_{2}\right]$ & 1620 & 3304 & -- & 406 & 310 & $\begin{array}{c}10.85(\mathrm{~s}, 1 \mathrm{H}, \mathrm{NH}) \\
8.4(\mathrm{~s}, 1 \mathrm{H}, \mathrm{H}-\mathrm{C}=\mathrm{N}) \\
7.2-7.8(\mathrm{~m}, 9 \mathrm{H}, \mathrm{Ar}-\mathrm{H})\end{array}$ \\
\hline$\left[\mathrm{Pd}(\mathrm{MQBO}) \mathrm{Cl}_{2}\right]$ & 1614 & -- & 996 & 398 & 306 & $\begin{array}{c}8.3(\mathrm{~s}, 1 \mathrm{H}, \mathrm{H}-\mathrm{C}=\mathrm{N}) \\
7.1-8.0(\mathrm{~m}, 9 \mathrm{H}, \mathrm{Ar}-\mathrm{H})\end{array}$ \\
\hline$\left[\mathrm{Rh}(\mathrm{MQBD})_{2} \mathrm{Cl}_{2}\right]$ & 1636 & 3294 & -- & 408 & 340 & $\begin{array}{c}10.9(\mathrm{~s}, 1 \mathrm{H}, \mathrm{NH}) \\
\text { 8.4 (s, 1H, H-C=N)} \\
7.2-7.8(\mathrm{~m}, 9 \mathrm{H}, \mathrm{Ar}-\mathrm{H})\end{array}$ \\
\hline$\left[\mathrm{Rh}(\mathrm{MQBO})_{2} \mathrm{Cl}_{2}\right]$ & 1618 & -- & 1004 & 400 & 335 & $\begin{array}{c}8.3(\mathrm{~s}, 1 \mathrm{H}, \mathrm{H}-\mathrm{C}=\mathrm{N}) \\
7.1-8.0(\mathrm{~m}, 9 \mathrm{H}, \mathrm{Ar}-\mathrm{H})\end{array}$ \\
\hline$\left[\mathrm{Ru}(\mathrm{MQBD})_{2} \mathrm{Cl}_{2}\right]$ & 1624 & 3310 & -- & 404 & 318 & $\begin{array}{c}10.8(\mathrm{~s}, 1 \mathrm{H}, \mathrm{NH}) \\
8.4(\mathrm{~s}, 1 \mathrm{H}, \mathrm{H}-\mathrm{C}=\mathrm{N}) \\
7.2-7.8(\mathrm{~m}, 9 \mathrm{H}, \mathrm{Ar}-\mathrm{H})\end{array}$ \\
\hline$\left[\mathrm{Ru}(\mathrm{MQBO})_{2} \mathrm{Cl}_{2}\right]$ & 1624 & -- & 998 & 402 & 316 & $\begin{array}{c}8.3(\mathrm{~s}, 1 \mathrm{H}, \mathrm{H}-\mathrm{C}=\mathrm{N}) \\
7.1-8.0(\mathrm{~m}, 9 \mathrm{H}, \mathrm{Ar}-\mathrm{H})\end{array}$ \\
\hline
\end{tabular}




\section{${ }^{I} H$ NMR spectra}

All the compounds show the ${ }^{1} \mathrm{H}$ NMR signals for different kinds of protons at their respective positions. The data are shown in Table 2. The ${ }^{1} \mathrm{H}$ NMR spectra of the ligand MQBD exhibit a singlets at $10.80 \delta(\mathrm{s}, \mathrm{N}-\mathrm{H})$ and $8.6 \delta(\mathrm{s}, \mathrm{H}-\mathrm{C}=\mathrm{N})$. The ${ }^{1} \mathrm{H}$ NMR spectra of complexes slightly changed compared to those of the corresponding ligand, and the signals appeared downfield, as expected, due to the coordination of nitrogen atoms to the metal ion ${ }^{18-20}$. ${ }^{1} \mathrm{H}$ NMR spectrum of MQBO ligand showed signals at $\delta 8.4(\mathrm{~s}, 1 \mathrm{H}, \mathrm{H}-\mathrm{C}=\mathrm{N}), 7.3-$ $8.0(\mathrm{~m}, 11 \mathrm{H}, \mathrm{Ar}-\mathrm{H})$ and $2.6\left(\mathrm{~s}, 3 \mathrm{H}, \mathrm{CH}_{3}\right)$. In the spectra of complexes, all signals remained at same position except the signal of $\mathrm{H}-\mathrm{C}=\mathrm{N}$. This is probably due to the coordinating effect of the azepine oxygen atom.

\section{Antibacterial Activity}

The comparison of inhibition zone values for the metal complexes (Table 3) reveals that the antimicrobial activity could be mainly due to the structure of the complexes and also the oxidation state of the metal ions. These results must be directly related to the greater biological activity exhibited by the square planar Pd(II) complexes compared to the octahedral $\mathrm{Rh}(\mathrm{III})$ and $\mathrm{Ru}(\mathrm{III})$ complexes.

Table 3. Inhibition zone of bacterial growth ( $\mathrm{mm})$

\begin{tabular}{lcccccc}
\hline \multirow{2}{*}{ Compound } & \multicolumn{3}{c}{ P.aerugenosa } & \multicolumn{3}{c}{ S.aureus } \\
& $0.1 \%$ & $0.2 \%$ & $0.3 \%$ & $0.1 \%$ & $0.2 \%$ & $0.3 \%$ \\
\hline MQBD & 1.2 & 1.6 & 2.8 & 1.4 & 1.8 & 3.0 \\
MQBO & 1.1 & 2.0 & 3.0 & 1.3 & 1.6 & 2.9 \\
{$\left[\mathrm{Pd}(\mathrm{MQBD}) \mathrm{Cl}_{2}\right]$} & 2.3 & 2.8 & 4.5 & 2.4 & 3.2 & 5.2 \\
{$\left[\mathrm{Rh}(\mathrm{MQBD})_{2} \mathrm{Cl}_{2}\right]$} & 1.5 & 1.9 & 3.2 & 1.6 & 2.1 & 3.4 \\
{$\left[\mathrm{Ru}(\mathrm{MQBD})_{2} \mathrm{Cl}_{2}\right]$} & 1.3 & 1.9 & 3.0 & 1.6 & 2.1 & 3.3 \\
{$\left[\mathrm{Pd}(\mathrm{MQBO}) \mathrm{Cl}_{2}\right]$} & 1.9 & 3.2 & 4.3 & 2.2 & 3.0 & 4.7 \\
{$\left[\mathrm{Rh}(\mathrm{MQBO})_{2} \mathrm{Cl}_{2}\right]$} & 1.4 & 2.4 & 3.4 & 1.5 & 2.0 & 3.2 \\
{$\left[\mathrm{Ru}(\mathrm{MQBO})_{2} \mathrm{Cl}_{2}\right]$} & 1.4 & 2.4 & 3.3 & 1.4 & 1.9 & 3.1 \\
\hline
\end{tabular}

A possible explanation for the high toxicity of metal complexes can be explained as follows. The increase in the activity of metal complexes may be due to effect of metal ions on the normal cell process. The polarity of metal ion is considerably reduced on chelation which is mainly because of partial sharing of its positive charge with a donor groups and possibly $\pi$ electron delocalization over the whole molecule. Such molecule increases the liphophilic character of the metal complexes which probably leads to break down of permeability barrier of the cells resulting in interference with normal cell process ${ }^{21}$. Better activities of the metal complexes as compared to free ligand could also be understood in terms of chelation theory ${ }^{22}$, which explains that a decrease in polarizability of the metal could enhance the liphophilicity of the complexes. 


\section{Antifungal activity}

The percentage inhibition values of fungicidal growth are recorded in Table 4. The screening data clearly shows that the complexes were more toxic than their parent ligand under identical experimental conditions and as the concentration of the complexes increases the inhibition of the fungal growth increases.

Table 4. Percentage inhibition of fungicidal growth.

\begin{tabular}{lcccccccccc}
\hline \multirow{2}{*}{ Compound } & \multicolumn{3}{c}{ C. albicans } & \multicolumn{3}{c}{ A. niger } & \multicolumn{4}{c}{ A. flavus } \\
& $0.1 \%$ & $0.2 \%$ & $0.3 \%$ & $0.1 \%$ & $0.2 \%$ & $0.3 \%$ & $0.1 \%$ & $0.2 \%$ & $0.3 \%$ \\
\hline $\mathrm{MQBD}$ & 11.2 & 13.8 & 18.3 & 10.3 & 13.4 & 20.2 & 9.8 & 13.1 & 24.2 \\
$\mathrm{MQBO}$ & 10.3 & 12.9 & 16.9 & 8.8 & 11.9 & 18.6 & 7.8 & 11.8 & 22.3 \\
{$\left[\mathrm{Pd}(\mathrm{MQBD}) \mathrm{Cl}_{2}\right]$} & 13.6 & 21.5 & 30.5 & 13.5 & 17.2 & 23.5 & 12.6 & 15.6 & 27.8 \\
{$\left[\mathrm{Rh}(\mathrm{MQBD})_{2} \mathrm{Cl}_{2}\right]$} & 11.5 & 14.4 & 21.8 & 10.8 & 13.9 & 20.9 & 10.4 & 13.2 & 24.9 \\
{$\left[\mathrm{Ru}(\mathrm{MQBD})_{2} \mathrm{Cl}_{2}\right]$} & 11.4 & 14.2 & 21.5 & 10.7 & 13.8 & 20.8 & 10.3 & 13.1 & 24.8 \\
{$\left[\mathrm{Pd}(\mathrm{MQBO}) \mathrm{Cl}_{2}\right]$} & 12.4 & 20.0 & 29.5 & 12.3 & 15.2 & 21.3 & 10.5 & 14.6 & 25.6 \\
{$\left[\mathrm{Rh}(\mathrm{MQBO})_{2} \mathrm{Cl}_{2}\right]$} & 10.9 & 14.1 & 21.2 & 9.5 & 12.6 & 19.1 & 8.4 & 12.6 & 23.0 \\
{$\left[\mathrm{Ru}(\mathrm{MQBO})_{2} \mathrm{Cl}_{2}\right]$} & 10.8 & 13.8 & 20.3 & 9.3 & 12.4 & 18.9 & 8.3 & 12.5 & 22.9 \\
\hline
\end{tabular}

\section{References}

1. Chiari E, Oliveira AB, Prado MAF, Alves RJ, Galvno LM and Araujo FG, J.Antimicrob.Agents Chemother., 1996,40,613.

2. Kim K, Kim H, Park K and Cho K, J.Korean Chem.Soc. 1998,42,236.

3. Jonckers TH, Miert SV, Cimanga K, Bailly C, Colson P, Gillet MC and Pauw D, J.Med.Chem., 2002,45(16),3497.

4. Dassonneville L, Lansiaux A, Wattelet A, Wattez N, Mahievu C and Miert SV. Eur.J.Pharmacol, 2000,409(1),9.

5. Godlewska J, Badowoska K, Ramza J, Kaczmarek L, Peczynska-Czoch and Opolski A, Radiol Oncol., 2004,38(2),137.

6. O'Neill PM, Bray PG, Hawley SR, Ward SA and Park BK, Pharmacol.Ther., 1998,77(1),29.

7. Foley M and Tilley L, Pharmacol.Ther., 1998,79(1),55.

8. Fahy PC and Persley GJ, Bacterial Diseases, Diagnostic Guide, New York, Academic Press, 1983.

9. Batemann E, U.S.Depat. Of Agril Tech. Bull., 1933,1,346.

10. Vincent J, Nature, 1947,159,580.

11. Ramappa PG and Somashekharappa KG, Indian J.Chem., 1994,33A, 67.

12. Ramappa PG and Somashekharappa KG, Asian J.Chem., 1993,5,41.

13. Ramachandra B and Narayana B, J.Indian Chem Soc., 2000,77,440.

14. Figgis BN and Lewis J, Prog.Inorg.Chem., 1964,6,37.

15. Lever ABP, Inorganic Electronic spectroscopy, Elsevier, Amsterdam, 1984.

16. Kalluraya B, Gururaja R and Ganesha Rai, Indian J.Chem., 2003,42B,211.

17. Bhojya Naik HS, Chetana PR and Revanasiddappa HD, J Indian Che.Soc., 2002,79, 955.

18. Gupta A, Sirohi R, Shastri S and Kishore D, J.Indian Chem.Soc., 2004,81,163.

19. S.Sampath Kumar and S.P.Rajendran, Asian J.Chem., 2004, 6, 3.

20. Mogilaiah K, Prasanthi M and Vidya K, Indian J.Chem., 2004,43B,2641.

21. Ramappa PG and Somashekarappa KG, J.Inorg.Biochem., 1994,55,13.

22. Srivastava RS, Inorg.Chim.Acta., 1981,56,L65. 


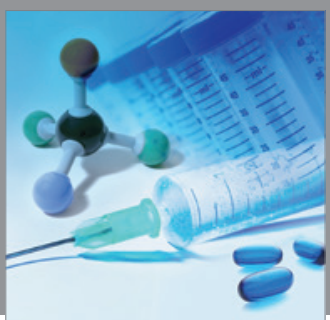

International Journal of

Medicinal Chemistry

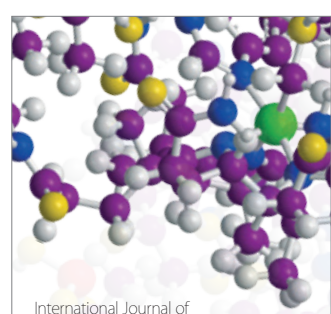

Carbohydrate Chemistry

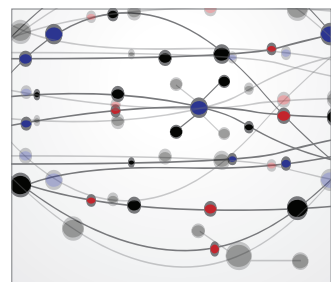

The Scientific World Journal
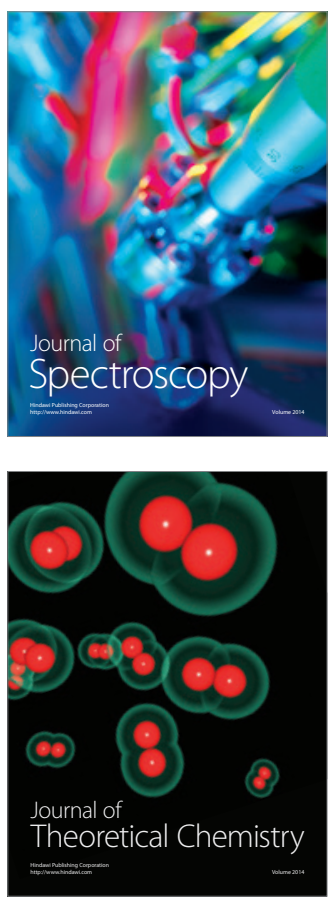
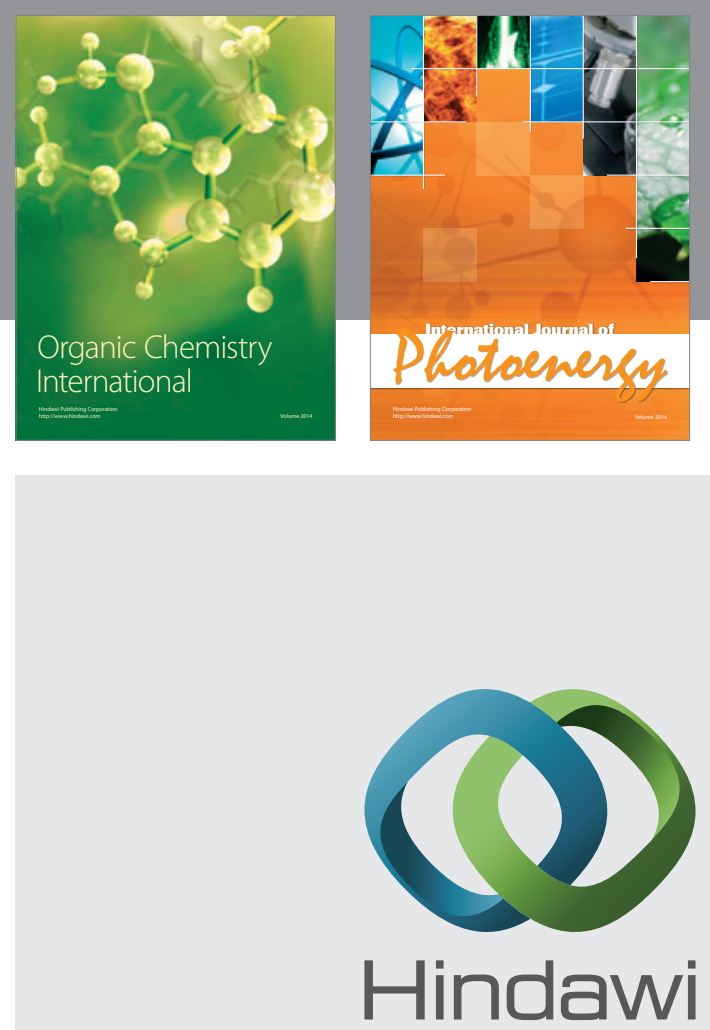

Submit your manuscripts at

http://www.hindawi.com
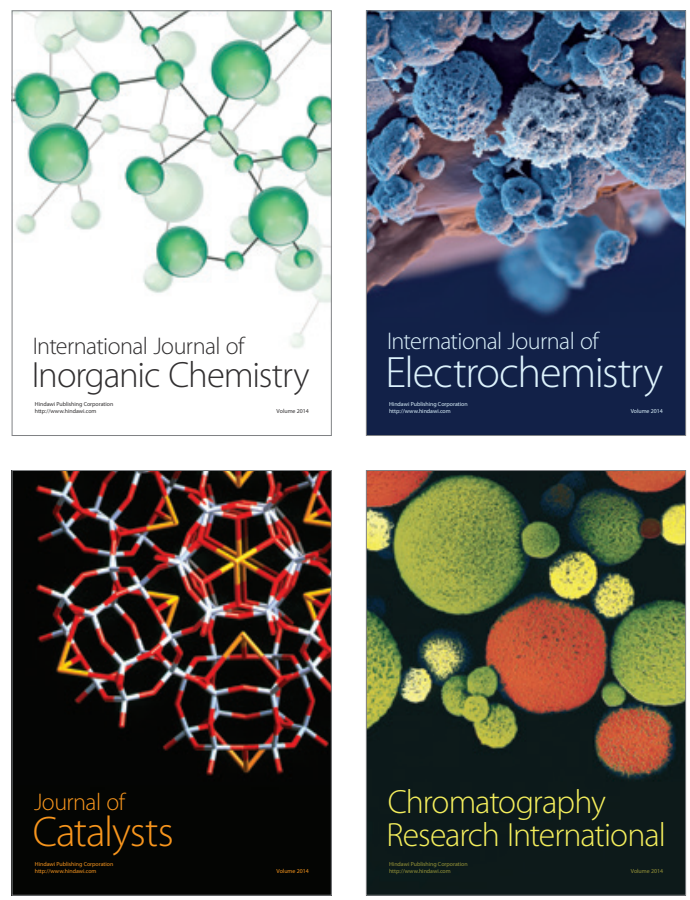
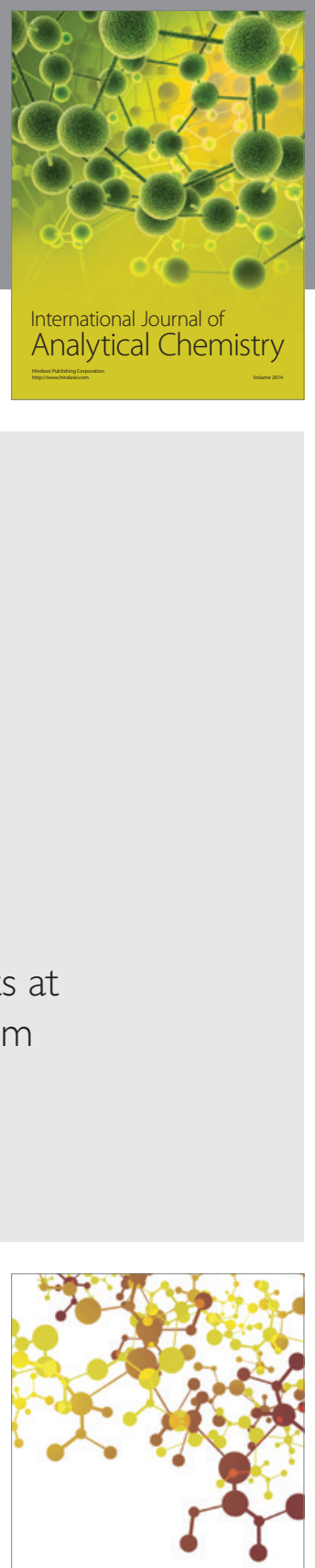

Journal of

Applied Chemistry
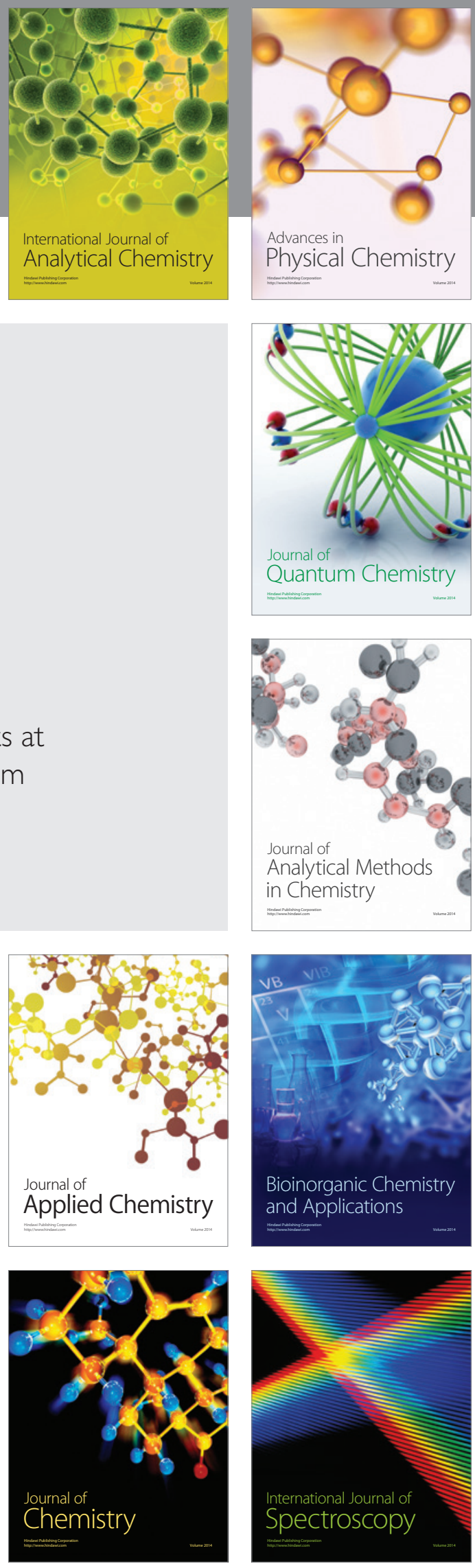